JURNAL PENDIDIKAN ISLAM IQRA'

Vol. 9. Nomor 1, Tahun 2015

Fakultas Tarbiyah dan Ilmu Keguruan [FTIK]

IAIN Manado

\title{
Internalisasi Nilai-Nilai Pluralisme dalam Pendidikan Islam
}

\section{Ikmal}

Institut Agama Islam Negeri Manado

\begin{abstract}
Abstrak
Diktum Bhinneka Tunggal Ika hanya menjadi jargon penguasa belaka, belum menempati kesadaran kognitif masyarakat mayoritas, dan tidak diimplementasikan secara nyata dan tepat dalam kehidupan sosial masyarakat sehari-hari. Berbagai konflik bernuansa SARA yang terjadi beberapa tahun silam, merupakan kegagalan bangsa Indonesia memahami pluralitas. Secara spesifik pendidikan juga dituding telah gagal memainkan perannya dalam menjalin keragaman melalui pembelajaran yang melampaui sekat-sekat agama. Pendidikan agama yang seharusnya dapat dijadikan sebagai wahana untuk mengembangkan moralitas universal yang ada dalam agama-agama sekaligus mengembangkan teologi inklusif dan pluralis, selama ini malah cenderung menampilkan wajahnya yang eksklusif dan dogmatis. Akibatnya, cita-cita luhur untuk mencapai masyarakat majemuk yang harmonis masih menjadi impian.
\end{abstract}

Keyword : Pluralisme-Agama-Pendidikan.

\section{Pendahuluan}

Dewasa ini wacana pluralisme agama menjadi wacana yang mulai digembargemborkan kembali, terutama di Indonesia. Hal ini tidak terleplas seiring munculnya berbagai kekerasan yang mengatasnamakan agama. Agama dipandang sebagai sumber pemicu konflik antar umat beragama itu sendiri. Konflik semacam itu sangat mungkin terjadi bahkan intensitasnya bisa lebih tinggi jika melihat konteks Indonesia yang multi agama dan dari masing-masing agama mengajarkan bahwa dirinyalah yang paling benar sedangkan yang lain salah. Karena itulah konflik yang 


\section{JURNAL PENDIDIKAN ISLAM IQRA'}

Vol. 9. Nomor 1, Tahun 2015

Fakultas Tarbiyah dan Ilmu Keguruan [FTIK]

IAIN Manado

mengatasnamakan agama di Indonesia tergolong permasalahan yang rawan terjadi sehingga perlu adanya ajaran tentang Pluralitas Agama. ${ }^{1}$

Asas historitas bangsa Indonesia sendiri merupakan negara yang ber-Bhineka Tunggal Ika, yang terdiri dari keragaman suku bangsa dan budayanya yang berarti persatuan dalam perbedaan merupakan semboyan negara Republik Indonesia. Sebagai negara dengan latar belakang budaya, suku, bahasa, dan agama yang sangat majemuk, Indonesia memerlukan pendekatan dan instrumen strategik yang dapat dijadikan sebagai sebuah gerakan nasional untuk mewujudkan persatuan, kesatuan, dan keutuhan bangsa agar menjadi bangsa yang berdaulat dan bermartabat. Salah satu instrumen pendekatannya adalah melalui pendidikan berbasis nilai-nilai pluralisme.

Ada persoalan krusial yang masih seringkali muncul pada bangsa ini adalah persoalan pluralisme. Kekerasan berlatarbelakang suku, agama, ras, antargolongan/kelompok (SARA), yang tidak jarang menimbulkan jatuhnya korban, bahkan mengancam disintegrasi bangsa adalah indikasi jelas tentang masih adanya persoalan bangsa yang hingga kini belum terselesaikan secara tuntas. Jika pluralisme tidak dikelola dengan baik, bukan tidak mungkin itu akan menjadi persoalan abadi.

Konsep pluralisme sendiri telah berkembang pesat di Indonesia, dan diserukan oleh berbagai pihak, Namun pemahaman tentang pluralisme cukup beragam. Khususnya lembaga pendidikan sebagai agen perubahan perlu mengkaji kembali konsep pendidikan yang berbasis nilai-nilai pluralisme.

Dalam Encyclopedia of Knowledge disebutkan bahwa pluralisme dapat dipahami sebagai "a theory or system of thought that recognizes more than one and generally more than two ultimate principles".2 Dari terminologi tersebut dapat

\section{2.}

${ }^{1}$ Quantum, Menyempurnakan Pendidikan Pluralisme, (Semarang: LPM EDUKASI, 2011), h.

${ }^{2}$ Grolier, Encyclopedia of Knowledge, Jilid XV (Danbury: Grolier Incorporated, 1993), h. 72. 


\section{JURNAL PENDIDIKAN ISLAM IQRA'}

Vol. 9. Nomor 1, Tahun 2015

Fakultas Tarbiyah dan Ilmu Keguruan [FTIK]

IAIN Manado

dipahami bahwa pluralisme merupakan sebuah teori atau sistem pemikiran yang mengakui lebih dari satu dan umumnya lebih dari dua prinsip-prinsip yang utama.

Sementara Dalam Kamus Besar Bahasa Indonesia Pluralisme berasal dari kata 'Plural' yang diartikan sebagai hal yang mengatakan jamak atau tidak satu, dalam arti berbeda-beda. Pluralitas adalah kemajemukan yang didasari oleh keutamaan (keunikan) dan kekhasan. ${ }^{3}$

Sedangkan dalam ilmu-ilmu sosial, pluralisme diartikan sebagai " a framework of interaction in which groups show sufficient respect and tolerance of each other, that they fruitfully coexist and interact without conflict or assimilation." 4 yaitu suatu kerangka interaksi yang mana setiap kelompok menampilkan rasa hormat dan toleran satu sama lain, berinteraksi tanpa konflik atau asimilasi (pembauran / pembiasan).

Masykuri Abdillah menyebut keragaman dengan sebutan pluralisme sosial atau primordial karena di dalamnya terdapat toleransi keragaman etnis atau kelompok-kelompok kultural dalam suatu masyarakat atau negara serta keragaman kepercayaan atau sikap dalam suatu badan, kelembagaan dan sebagainya. ${ }^{5}$ Kelompok etnis, agama, suku, agama dan budaya hidup bersama dalam sebuah bangsa. ${ }^{6}$

Pluralisme agama dinegeri ini merupakan realitas empirik yang tidak bisa dipungkiri. Plurisme sejak dulu telah dikenal sebagai potensi berbangsa dan bernegara, menetapkan negara ini bukan menjadi negara agama atau negara sekuler. Pilihannya berada tepat ditengah - tengah antara kedunya.

${ }^{3}$ Departemen Pendidikan dan Kebudayaan, Kamus Besar Bahasa Indonesia (Cet. III; Jakarta: Balai Pustaka, 1990), h. 691

${ }^{4}$ Ibid.

${ }^{5}$ Lihat Syamsul Ma'arif, Pendidikan Pluralisme di Indonesia (Cet.I; Jogjakarta:Logung Pustaka, 2005), h. 13.

'Syafiq Hasyim, “Multikulturalisme Baru Barat-Islam”, Kompas, Sabtu, 3 Februari 2006, h. 06 . 
JURNAL PENDIDIKAN ISLAM IQRA'

Vol. 9. Nomor 1, Tahun 2015

Fakultas Tarbiyah dan Ilmu Keguruan [FTIK]

IAIN Manado

Adapun yang dimaksud dengan "pluralisme agama" adalah paham yang memandang bahwa kebenaran itu banyak atau majemuk yang bersifat partikular dengan pengabsahan teologis terhadap agama lain. ${ }^{7}$ Paham ini dianut oleh kaum parennialisme dengan sikap keagamaan yang inklusif ${ }^{8}$ yang memandang bahwa setiap agama mengandung "Inner metaphysical truth of religions" yang kebenarannya bersifat transenden yang terletak dalam "intelek" Ilahy. Namun menurut Nasr - salah satu tokoh parennialisme- kesamaan agama hanya terletak pada level esensi tertinggi yang berdiri di atas semua perbedaan dan keragaman lahiriah kosmik. Pada tingkat bawah, di kawasan dunia empiris nampak perbedaan dari sudut syariah dan aturan-aturan ritualnya. ${ }^{9}$

Menurut Nurcholish Madjid bahwa semua agama sama karena sama-sama bersumber dari Tuhan. Semua Nabi dan Rasul membawa misi yang mengajarkan petunjuk Allah, karena itu umat Islam harus mengakui kebenaran agama-agama lain. Namun Islam mempunyai keistimewaan dari agama lain yakni selalu sejalan dengan semangat ilmiah dan sikap hidup modern.

Sejalan dengan apa yang diungkapkan Andreas, apabila kita berbicara mengenai pluralisme agama-agama, kita tidak membatasi diri hanya pada agamaagama yang diakui negara, melainkan juga yang berada di luarnya. Tetapi untuk mengakui kenyataan ini, kepada kita dituntut kedewasaan beragama. Tercakup di dalam kedewasaan beragama adalah pengakuan bahwa orang lainpun berhak untuk menyatakan imannya di muka umum. Tentu saja apa yang diungkapkan itu tidak

7 Nurcholis Madjid, Mencari Akar-Akar Islam bagi Pluralisme Modern (Bandung: Mizan, 1993), h. 23.

${ }^{8}$ Moh. Natsir Mahmud, Bunga Rampi Epistemologi dan Metode Studi Islam (Ujung Pandang : IAIN Alauddin Ujung Pandang, 1998), h. 64.

${ }^{9}$ Sayyed Husein Nasr, Knowlegde and The Sacred, diterjemahkan oleh Suharsono, dkk. Dengan judul Inteligensi dan Spiritualitas Agama-Agama (Cet. I; Jakarta: Inisari Press, 2004), h. 97. 


\section{JURNAL PENDIDIKAN ISLAM IQRA'}

Vol. 9. Nomor 1, Tahun 2015

Fakultas Tarbiyah dan Ilmu Keguruan [FTIK]

IAIN Manado

harus sesuai dengan iman seseorang, namun seseorang tersebut tidak boleh merasa terganggu dengan itu selama yang bersangkutan melakukannya dengan cara-cara yang berkeadaban. ${ }^{10}$

Sebagai contoh, ada satu daerah di Indonesia yang damai dan pluralis, Mopuya, sebuah dusun di kecamatan Dumoga Utara, kabupaten Bolmong, Provinsi Sulawesi Utara (Sulut) memiliki karakter yang damai, toleran, dan pluralis. Desa terpencil di Provinsi Sulut ini dihuni penduduk dari berbagai agama: Islam, Hindu, Katolik, dan Kristen dari berbagai denominasi. Uniknya mereka membangun tempat ibadah bersama-sama, dan bahkan di desa Mopuya Selatan tempat-tempat ibadah itu dibangun dalam satu komplek di sebuah lahan yang disediakan oleh pemerintah setempat. Di komplek ini terdapat Masjid Jami' al-Muhajirin, Pure Puseh Umat Hindu, Gereja Katolik Santo Yusuf Mopuya, Gereja Pantekosta, Gereja KGPM Sidang Kalvari Mopuya, dan GMIBM PGI Jemaat Immanuel Mopuya. Tidak sebatas itu, komunitas agama di desa ini juga saling merayakan hari-hari besar agama mereka dalam semangat penuh kebersamaan dan saling menghargai perbedaan dan keragaman. Para tokoh agama juga tidak mengajarkan superioritas agamanya atas yang lain. Karena karakteristiknya yang unik, damai, toleran, dan pluralis, desa ini pernah menjadi "proyek percontohan" atau model toleransi dan pluralisme agama bagi masyarakat internasional. Bahkan mantan Menteri Agama Tarmizi Taher dan Gubernur EE Mangindaan pernah diundang pemerintah Amerika Serikat untuk presentasi mengenai kehidupan keberagama an di Indonesia, terutama komunitas Mopuya ini (Jawa Pos, 18 Maret 2008). Terlepas dari kemampuan masyarakat Mopuya untuk mentransformasikan keberagaman dalam spirit toleransi, persaudaraan, dan pluralisme serta mengelola perbedaan dalam bentuk tindakan positif, Sulut memang dikenal sebagai salah satu daerah yang sepi dari kekerasan

${ }^{10}$ Merayakan Kebebasan Beragama, Bunga Rampai 70 Tahun Djohan Effendi(Yayasan Abad Demokrasi: Jakarta, 2011), h. 80. 


\section{JURNAL PENDIDIKAN ISLAM IQRA'}

Vol. 9. Nomor 1, Tahun 2015

Fakultas Tarbiyah dan Ilmu Keguruan [FTIK]

IAIN Manado

sosial di Indonesia. Tidak seperti Maluku, Maluku Utara, Sulawesi Tengah, Sulawesi Selatan, Kalimantan Tengah, Lombok, Sumatra Barat dan sebagainya yang rawan konflik dan kekerasan, masyarakat Sulut dikenal mampu me-manage potensi konflik dengan baik sehingga tidak berubah menjadi kekerasan komunal. Kekerasan, apapun jenisnya, termasuk "kekerasan berbasis agama" terjadi karena individu atau kelompok tertentu tidak mampu menyelesaikan konflik yang inherent dalam setiap manusia itu dengan cara-cara "civil" dan dialog. ${ }^{11}$

Dari berbagai uraian di atas, definisi seharusnya mencover semua jenis agama, kepercayaaan, sekte maupun berbagai jenis idiologi modern seperti komunisme, humanisme, sekularisme, nasionalisme dan lainnya. Jadi pluralisme agama merupakan kondisi hidup bersama antar agama yang berbeda beda dalam satu komunitas dengan tetap mempertahankan ciri spesifik dalam ajaran masingmasing agama.

Jadi Pluralisme seharusnya bukan hanya sekedar pluralitas, pluralisme harus mengakomodir dan memahami seluruh keanekaragaman dan kemajemukan nilai-nilai dasar dari pluralisme yaitu nilai kesamaan dan kebersamaan, sikap terbuka dalam menerima perbedaan yang ada (saling memahami), saling menghormati, saling menolong, prinsip kebebasan, keadilan.

Pengelolaan pluralisme ini bukan saja menyangkut penataan pluralisme itu sendiri secara benar, tetapi yang paling penting adalah membangun dan mengembangkan pluralisme dengan postur tubuhnya yang pas sesuai dengan format republik ini. Pendidikan merupakan media pencerdasan anak-anak bangsa yang dapat digunakan dalam membangun dan mengembangkan pluralisme untuk menjaga keutuhan dan membangun masa depan bangsa dan negara.

\section{Pembahasan}

\footnotetext{
${ }^{11}$ Ibid., h. 174.
} 


\section{JURNAL PENDIDIKAN ISLAM IQRA'}

Vol. 9. Nomor 1, Tahun 2015

Fakultas Tarbiyah dan Ilmu Keguruan [FTIK]

IAIN Manado

Pendidikan harus ditempatkan pada garda paling depan dalam mendekonstruksi teologi pluralisme dengan membuat metodologi pendidikan yang tepat untuk mendukungnya. Konstruksi pendidikan di masa lalu yang berbasiskan penyeragaman identitas budaya bangsa, misalnya harus dikaji dan mesti disesuaikan dengan paradigma pendidikan yang berbasis pluralisme bangsa.

Pendidikan agama pada khususnya sebagai media penyadaran umat perlu membangun teologi inklusif dan pluralis, dalam membentuk karakter individuindividu yang dididiknya, dan mampu menjadi "guiding light" bagi generasi muda penerus bangsa demi harmonisasi agama-agama. Salah satu peran dan fungsi pendidikan agama diantaranya adalah untuk meningkatkan keberagamaan peserta didik dengan keyakinan agama sendiri, dan keterbukaan untuk mempelajari dan mempermasalahkan agama lain sebatas untuk menumbuhkan sikap toleransi. ${ }^{12}$

Pendidikan agama merupakan bagian integral dari pendidikan pada umumnya dan berfungsi untuk membantu perkembangan pengertian yang dibutuhkan bagi orang-orang yang berbeda iman, sekaligus juga untuk memperkuat ortodoksi keimanan bagi mereka". ${ }^{13}$

Serentetan kerusuhan-kerusuhan yang berbau SARA di Indonesia, menunjukkan bahwa secara kolektif kita sebenarnya tidak mau belajar tentang bagaimana hidup secara bersama secara rukun. Bahkan, dapat dikatakan, agen-agen sosialisasi utama seperti keluarga dan lembaga pendidikan, tampaknya tidak berhasil menanamkan sikap toleransi-inklusif dan tidak mampu mengajarkan untuk hidup bersama dalam masyarakat plural. Di sinilah letak pentingnya sebuah ikhtiar menanamkan teologi pluralisme melalui pendidikan agama. Sehingga, masyarakat

\footnotetext{
${ }^{12}$ Lihat, John Sealy, Religious Education Philosophical Perspective (London: George Allen \& Unwin, 1985), h. 43-44.

${ }^{13}$ Lihat, Alex R. Rodger, Educational and Faith in Open Society (Britain: The Handel Press, 1982), h. 61 .
} 


\section{JURNAL PENDIDIKAN ISLAM IQRA'}

Vol. 9. Nomor 1, Tahun 2015

Fakultas Tarbiyah dan Ilmu Keguruan [FTIK]

IAIN Manado

Indonesia akan mampu membuka visi pada cakrawala yang semakin luas, mampu melintas batas kelompok etnis atau tradisi budaya dan agama. Inilah pendidikan akan nilai-nilai dasar kemanusiaan untuk perdamaian, kemerdekaan, dan solidaritas.

Mencermati realitas tersebut, pemikiran mengenai pentingnya pendidikan pluralisme, terutama bangsa Indonesia yang majemuk bukan tanpa alasan. Apakah yang disebut pendidikan pluralisme itu? Mungkin inilah yang menjadi pertanyaan banyak orang, karena memang bentuknya yang relatif baru dan belum disosialisasikan banyak orang. Kalaupun ada, itu pun masih berupa gagasan-gagasan mengenai arti pentingnya bentuk pendidikan pluralisme bagi masyarakat agama.

Magnes Suseno memberikan definisi pendidikan pluralisme. Ia menyatakan bahwa pendidikan pluralisme adalah pendidikan yang menginternalisasikan nilainilai dasar kemanusiaan untuk perdamaian, kemerdekaan, dan solidaritas agar visi kita mampu melintasi batas kelompok etnis atau tradisi budaya dan agama, sehingga kita mampu melihat "kemanusiaan" sebagai sebuah keluarga yang memiliki perbedaan maupun kesamaan cita-cita. ${ }^{14}$

Ainurrofiq Dawam menjelaskan definisi pendidikan multicultural (baca = pluralisme) sebagai proses pengembangan seluruh potensi manusia yang menghargai pluralitas dan heterogenitasnya sebagai konsekuensi keragamaan budaya etnis, suku, dan aliran (agama). ${ }^{15}$

Pengertian pendidikan multikultural yang demikian, tentu mempunyai implikasi yang sangat luas dalam pendidikan. Karena pendidikan itu sendiri secara umum dipahami sebagai proses tanpa akhir atau proses sepanjang hayat. Dengan demikian, pendidikan multikultural menghendaki penghormatan dan penghargaan setinggi-tingginya terhadap harkat dan martabat manusia dari mana pun datangnya

\footnotetext{
${ }^{14}$ Syamsul Ma'arif, Pendidikan Pluralisme di Indonesia, op.cit., h. 92

${ }^{15}$ Ibid.,
} 


\section{JURNAL PENDIDIKAN ISLAM IQRA'}

Vol. 9. Nomor 1, Tahun 2015

Fakultas Tarbiyah dan Ilmu Keguruan [FTIK]

IAIN Manado

dan berbudaya apa pun dia. Harapannya, sekaligus adalah terciptanya kedamaian yang sejati, keamanan yang tidak dihantui kecemasan, kesejahteraan yang tidak dihantui manipulasi, dan kebahagiaan yang terlepas dari jaring-jaring manipulasi rekayasa sosial.

Muhammad Ali menyebutnya sebagai pendidikan yang berorientasi pada proses penyadaran yang berwawasan pluralis secara agama sekaligus berwawasan multikultural sebagai upaya komprehensif mencegah dan menanggulangi konflik etnis agama, radikalisme agama, separatisme, dan integrasi bangsa, sedangkan nilai dasar dari konsep pendidikan ini adalah toleransi. ${ }^{16}$

Dengan demikian pendidikan pluralisme diharapkan seorang murid bisa diantarkan untuk dapat memandang pluralitas keindonesiaan dalam berbagai aspek sosial, ekonomi, politik, budaya, dan agama sebagai kekayaan spiritual bangsa yang harus tetap dijaga kelestariannya. Jika tidak, maka keindonesiaan itu sendiri yang akan menjadi taruhannya. Akhirnya, dengan model pendidikan pluralisme seperti ini, diharapkan mampu memberikan dorongan terhadap terciptanya perdamaian dan upaya menanggulangi konflik yang akhir-akhir ini marak, sebab nilai dasar dari pendidikan pluralisme adalah penanaman dan pembumian nilai toleransi, empati, simpati dan solidaritas sosial.

Tujuan pendidikan pluralisme adalah mendapatkan titik-titik pertemuan yang dimungkinkan secara teologis oleh masing-masing agama. bukanlah untuk membuat suatu kesamaan pandangan, apalagi keseragaman, karena ini adalah sesuatu yang absurd dan agak mengkhianati tradisi suatu agama. Yang dicari Setiap agama mempunyai sisi ideal secara filosofis dan teologis, dan inilah yang dibanggakan penganut agama, serta yang akan menjadikan mereka tetap bertahan, jika mereka mulai mencari dasar rasional atas keimanan mereka. Oleh karena itu, suatu dialog

\footnotetext{
${ }^{16}$ Ibid., h. 93 .
} 


\section{JURNAL PENDIDIKAN ISLAM IQRA'}

Vol. 9. Nomor 1, Tahun 2015

Fakultas Tarbiyah dan Ilmu Keguruan [FTIK]

IAIN Manado

dalam pendidikan pluralisme harus selalu mengandalkan kerendahan hati untuk membandingkan konsep-konsep ideal yang dimiliki agama lain.

Landasan filosofis pelaksanaan pendidikan pluralisme di Indonesia harus didasarkan pada pemahaman adanya fenomena bahwa "satu Tuhan, banyak agama" merupakan fakta dan realitas yang dihadapi manusia sekarang. Maka manusia Indonesia sekarang didorong menuju kesadaran bahwa pluralisme memang sunguhsungguh fitrah kehidupan manusia. selain itu, juga harus didasarkan pada suatu pengertian bahwa manusia memang berbeda. Tapi mereka juga memiliki kesamaankesamaman. Dan setidaknya dalam keadaan peradaban sekarang ini persamaanpersamaan mereka lebih penting ketimbang perbedaan-perbedaan di antara mereka.

Islam adalah agama rahmat lil alamin. Sejak kelahirannya, Islam sudah berada di tengah-tengah budaya dan agama-agama lain. Sebuah masyarakat pluralistik secara religius telah mapan pada saat itu. Oleh karenanya banyak ditemukan di dalam al-Qur'an tentang dialog antara Islam dengan agama-agama lainnya mengenai keimanan dengan konsep tauhidnya. ${ }^{17}$

Konsep tauhid (keesaan Tuhan) dalam Islam merupakan hal yang fundamental bagi landasan pluralisme. Dalam konsep tauhid, hanya Allah yang esa. Konsep ini menegasikan adanya keesaan di luar diri-Nya. Hal tersebut berarti bahwa tidak ada ketunggalan di alam dan masyarakat, yang ada hanya kemajemukan atau pluralitas.

Dalam tatanan konseptual, al-Qur'an telah memberi resep atau arahan-arahan yang sangat diperlukan bagi manusia muslim untuk memecahkan masalah kemanusiaan universal, yakni realitas pluralitas keberagaman manusia. Dan menuntut supaya bersikap toleransi terhadap kenyataan tersebut demi tercapainya perdamaian di muka bumi. Karena Islam menilai bahwa syarat untuk membuat keharmonisan

17 Amin Abdullah, Studi Agama: Normativitas atau Historisitas (Cet. I; Yogyakarta: Pustaka Pelajar, 1991), h. 73. 


\section{JURNAL PENDIDIKAN ISLAM IQRA'}

Vol. 9. Nomor 1, Tahun 2015

Fakultas Tarbiyah dan Ilmu Keguruan [FTIK]

IAIN Manado

adalah pengakuan terhadap komponen-komponen yang secara alamiah berbeda. Hal ini terlihat pada QS. Surah al-Kafirun (109) Ayat ; 6 yang berbunyi :

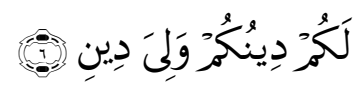

Terjemahnya:

Untukmu agamamu, dan untukkulah, agamaku."18

Perintah Islam agar umatnya bersikap toleran terhadap agama lainnya dengan menyatakan bahwa tidak ada paksaan dalam soal agama dan menyerahkan kepada manusia merdeka untuk memilih jalan yang dikehendakinya. Manusia tidak boleh memaksa manusia lainnya untuk mengikuti ajaran yang disampaikannya karena tugas manusia hanyalah mengajak manusia lainnya untuk menyembah kepada Allah, namun hanya Allah yang berhak memberi hidayah kepada seseorang. Hal ini terlihat pada QS. Yunus (10):99

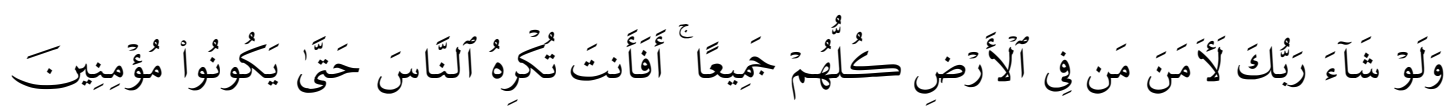

Terjemahnya :

Dan Jikalau Tuhanmu menghendaki, tentulah beriman semua orang yang di muka bumi seluruhnya. Maka apakah kamu (hendak) memaksa manusia supaya mereka menjadi orang-orang yang beriman semuanya ?. ${ }^{19}$

Ayat ini menunjukkan bahwa tidaklah sulit bagi Allah untuk menyatukan umat manusia dalam satu agama, Karena Allah telah menakdirkan bahwa fikiran

${ }^{18}$ Ibid., h. 111.

${ }^{19}$ Ibid., h. 322 . 


\section{JURNAL PENDIDIKAN ISLAM IQRA'}

Vol. 9. Nomor 1, Tahun 2015

Fakultas Tarbiyah dan Ilmu Keguruan [FTIK]

IAIN Manado

manusia mampu mendapat petunjuk bagi orang yang berfikir dalam mencari keselamatan hidup, dan pilihan untuk berbuat baik. ${ }^{20}$

Al-Qur'an sebagai firman Allah tidak pernah menghendaki manusia menjadi umat yang satu yang diatur oleh satu konvensi atau satu gagasan. Manusia berbeda, dan akan terus berbeda baik dalam ras, bahasa, keyakinan, dan lainnya. ${ }^{21}$

Menurut Nurcholish Madjid, sebagai kepastian Tuhan, pluralitas itu secara teologis termasuk dalam kategori Sunnatullah yang tak terhindarkan. Kalau ada perbedaan dalam menumbuhkan pluralitas, perbedaan yang dapat ditenggang adalah perbedaan yang tidak membawa kerusakan kehidupan bersama sebagai prinsip etika agama. $^{22}$

Oleh karenanya, perbedaan antara satu umat dengan umat yang lain adalah fitrah dan sebuah keniscayaan serta satu kenyataan objektif komunitas umat manusia yang menjadi Sunnatullah yang tak terpisahkan dari kehidupan kita sehari-hari.

Wacana internalisasi nilai-nilai pluralisme dalam pendidikan Islam sejauh ini belum terlihat usaha serius baik dari pemerintah maupun dari tokoh-tokoh pendidikan Islam. Hal ini terlihat pada muatan kurikulumnya yang masih sangat eksklusif.

Olehnya itu, kurikulum pendidikan Islam seharusnya memuat atau merancang kurikulum berbasis nilai-nilai pluralisme seperti nilai kesamaan dan kebersamaan, sikap terbuka dalam menerima perbedaan yang ada (saling memahami), saling menghormati, saling menolong, prinsip kebebasan, keadilan, persamaan hak dan kewajiban, kasih sayang, kebajikan, kedamaian, terbuka untuk melakukan kerja sama dalam berbagai bidang. Hal ini dapat dituangkan dalam buku daras agar menjadi

${ }^{20}$ Muni'in A. Sirry, Dilema Islam, Dilema Demokrasi Pengalaman Baru Muslim dalam Transisi Indonesia (Cet. I; Jakarta: PT. Gugus Press, 2002), h. 146.

${ }^{21}$ Gamal al-Banna, Doktrin Pluralisme dalam al-Qur'an (Jakarta: Menara, 2006), h. 12.

${ }^{22}$ Budhy Munawar, Tugas Cendekia Muslim: Modernisme dan Tantangan Pluralisme Keagamaan, dalam Kebebasan Cendekiawan, (Yogyakarta: Pustaka Republika, 1996), h. 235. 


\section{JURNAL PENDIDIKAN ISLAM IQRA'}

Vol. 9. Nomor 1, Tahun 2015

Fakultas Tarbiyah dan Ilmu Keguruan [FTIK]

IAIN Manado

acuan bagi para pendidik dalam menginternalisasikan nilai-nilai pluralisme dalam pembelajaran.

Ainul Yaqin mengungkapkan dari beberapa literatur yang dipelajari, bahwa nilai-nilai yang dikembangkan dalam pendidikan berbasis pluralisme sangat berorientasi pada hakikat dasar manusia dengan tidak menyisihkan sedikitpun dari keberadaannya. Nilai-nilai tersebut meliputi:

a) Menjunjung tinggi nilai-nilai kemanusiaan/humanitas

b) Kebebasan beragama bagi masyarakat

c) Demokrasi dalam semua aspek tatanan sosial

d) Toleransi antar sesama manusia

e) Rekonsiliasi/perdamaian di muka bumi

f) Cinta, kasih sayang, saling menolong, saling melindungi dan memberi keselamatan

g) Keadilan/kesetaraan/egaliter

h) Kemaslahatan sosial

i) Kelestarian budaya-budaya masyarakat. ${ }^{23}$

Berangkat dari nilai-nilai yang dikembangkan ini, maka sebenarnya tidaklah perlu diragukan atau dikhawatirkan adanya inisiatif atau ide untuk menyelenggarakan pendidikan yang berorientasi pluralisme dalam bentuk institusi pendidikan, apalagi dalam konteks ke-Indonesia-an.

Menurut Syamsul Ma'arif, Ketika pendidikan pluralisme hendak diaplikasikan pada konteks Indonesia, maka satu hal yang sangat mendasar untuk dipikirkan adalah persoalan kurikulum yang akan menjadi pijakannya, karena kurikulum adalah core-nya pendidikan. Ada beberapa pemikiran tentang kurikulum

\footnotetext{
${ }^{23}$ M. Ainul Yaqin, Pendidikan Multikultural: Cross-Cultural Understanding untuk Demokrasi dan Keadilan, (Yogyakarta: Pilar Media, 2005).
} 


\section{JURNAL PENDIDIKAN ISLAM IQRA'}

Vol. 9. Nomor 1, Tahun 2015

Fakultas Tarbiyah dan Ilmu Keguruan [FTIK]

IAIN Manado

yang harus diperhatikan oleh penyelenggara pendidikan pluralisme, antara lain sebagai berikut:

a) Pendidikan sekolah harus membekali peserta didik dengan kerangka yang memungkinkannya menyusun dan memahami pengetahuan yang diperoleh dari lingkungannya (UNESCO, 1981).

b) Kurikulum yang ideal adalah kurikulum yang dapat menunjang proses peserta didik menjadi manusia yang demokratis, pluralis, dan menekankan penghayatan hidup serta refleksi untuk menjadi manusia yang utuh, yaitu generasi yang tidak hanya pandai tetapi juga bermoral dan etis, dapat hidup dalam suasana demokratis satu dengan lain, dan menghormati hak orang lain.

c) Mengembangkan kurikulum sebagai proses, yakni:

1) posisi siswa sebagai subjek dalam belajar;

2) cara belajar siswa yang ditentukan oleh latar belakang budayanya;

3) lingkungan budaya mayoritas masyarakat dan pribadi siswa adalah entry behavior kultur siswa;

4) lingkungan budaya siswa adalah sumber belajar. ${ }^{24}$

Di samping pemikiran-pemikiran di atas, menurut Ainul Yaqin, ada beberapa criteria yang menjadi pedoman dalam penyusunan kurikulum pendidikan pluralisme yaitu sebagai berikut:

a. Penyusunan kurikulum harus didasarkan pada keimanan kepada Tuhan Yang Maha Esa, norma-norma atau nilai-nilai absolut yang diambil dari agamaagama besar dunia dan hubungan integral antara Tuhan, manusia, dan alam.

b. Karena ilmu pengetahuan datang dari Tuhan, maka manusia tidak dapat disebut sebagai pembuat ilmu pengetahuan (the creators of knowledge). Akan tetapi disebabkan manusia dapat dengan mudah menemukan aspek-aspek yang terkandung dalam dunia ini, maka nilai-nilai kemanusiaan dapat dijadikan

\footnotetext{
${ }^{24}$ Syamsul Ma'arif, op.cit.,
} 
JURNAL PENDIDIKAN ISLAM IQRA'

Vol. 9. Nomor 1, Tahun 2015

Fakultas Tarbiyah dan Ilmu Keguruan [FTIK]

IAIN Manado

sebagai inspirasi untuk menyeleksi, menginvestigasi, menerima, dan menikmati adanya sebuah kebenaran.

c. Peserta didik diharuskan mengetahui hirarkhi antara ilmu pengetahuan dan sumber nilai. Ilmu pengetahuan diperoleh melalui sebuah pengalaman yang harus tunduk terhadap pengetahuan rasional, dan pengetahuan rasional harus tunduk terhadap norma-norma agama yang datang dari Tuhan.

d. Keimanan dan nilai-nilai harus diakui sebagai dasar kebudayaan manusia. Oleh sebab itu, keduanya tidak boleh dipisahkan dalam proses belajar mengajar. Ilmu pengetahuan tidak harus ditunjukkan sebagai sesuatu yang bertentangan dengan pandangan agama. Dengan demikian, dalam pendidikan harus digunakan untuk mendorong value atau nilai-nilai yang baik.

e. Manusia tidak dapat mengetahui kebenaran absolut, tetapi suatu kebenaran dapat direalisasikan pada level yang berbeda-beda melalui perasaan, pemikiran, institusi, dan intelektual. Keempat bentuk ini harus bekerja secara harmoni dan terintegrasikan ke dalam sebuah sistem pendidikan yang komprehensif.

f. Peserta didik harus didorong untuk mengetahui prinsip-prinsip unity and diversity dan menyadari adanya dasar-dasar keamanan yang menembus dunia biologis dan psikis. Ini sebuah refleksi terhadap sebuah kesatuan prinsip-prinsip penciptaan dunia. Dunia adalah sebuah sistem yang mempersatukan (the universe is a unified system) dan terdapat suatu hubungan integral di atara bagian-bagian yang berbeda-beda. ${ }^{25}$

Pendidikan Islam Berbasis nilai-nilai Pluralisme dapat diterapkan dalam pengembangan model-model pengembangan PAI di sekolah atau perguruan tinggi. Dalam hal terdapat tiga model yang dikemukan oleh para ahli.

\footnotetext{
${ }^{25}$ M. Ainun Najib mengutip dari dari Syeikh Abdul Mahbub, “An Integrated Education System in A Multi-Faith and Multi-Cultural Country", (1991), h. 39-44.
} 


\section{JURNAL PENDIDIKAN ISLAM IQRA'}

Vol. 9. Nomor 1, Tahun 2015

Fakultas Tarbiyah dan Ilmu Keguruan [FTIK]

IAIN Manado

a) Model Dikotomi, pada model ini, aspek kehidupan dipandang dengan sangat sederhana. Segala hal yang ada hanya dipandang dari dua sisi, seperti laki-laki dan perempuan, ada dan tidak ada, pendidikan agama dan non agama dan lain sebagainya. Pandangan ini akan berimplikasi pada pengembangan ukhrowi saja, pendidikan yang bersifat duinawi tidaklah penting. Model ini berkembang pada periode pertengahan dalam sejarah pendidikan Islam.

b) Model Mekanisme, model ini memamdang kehidupan dari berbagai aspek, dan pendidikan dipandang sebagai penanaman dan pengembangan seperangkat nilainilai kehidupan yang terdiri atas nilai agama, nilai individu, nilai sosial, nilai politik, nilai ekonomi dan nilai-nilai yang lain. Model tersebut dikembangkan pada sekolah atau PT yang bukan berciri khas agama Islam, namun mungajarkan mata pelajaran atau mata kuliah agama Islam.

c) Model Sistemik, dalam konteks ini pendidikan Islam dipandang sebagai aktifitas yang terdiri atas komponen-komponen yang hidup bersama dan bekerja sama dengan tujuan tertentu, yaitu terwujudnya hidup yang religius. Model ini diterapkan oleh madrasah atau sekolah swasta Islam unggulan. ${ }^{26}$

Namun berhasil dan tidaknya suatu tujuan pendidikan berbasis pluralisme, tergantung pada pendekatan dan metode yang digunakannya. Tidak relevannya pendekatan dan metode yang di kembangkan dalam pembelajaran pendidikan agama berbasis pluralisme seperti ini perlu di perhatikan adanya beberapa pendekatan yang dapat di gunakan antara lain:

a) Pembiasaan, melaksanakan pembelajaran dengan membiasakan sikap dan perilaku yang baik, terutama sekali yang berhubungan dengan nilai seperti: tenggang rasa, toleransi, saling mengasihi, tolong menolong dll.

${ }^{26}$ Muhaimin, Rekonstruksi Pendidikan Islam, (Jakarta: PT Raja Grafindo Persada, 2009), h. 5968. 


\section{JURNAL PENDIDIKAN ISLAM IQRA'}

Vol. 9. Nomor 1, Tahun 2015

Fakultas Tarbiyah dan Ilmu Keguruan [FTIK]

IAIN Manado

b) Rasional, pendekatan yang memfungsikan rasio peserta didik, sehingga isi dan nilai yang di tanamkan mudah di pahami dengan penalaran. Disisi lain pendekatan akademis cenderung menempatkan proses pendidikan agama pada orientasi objektif.

c) Emosional, upaya menggugah perasaan peserta didik dalam memahami realitas keanekaragaman budaya dan agama dalam masyarakat. Sehingga lebih terkesan dalam jiwa peserta didik untuk selalu menampilkan sikap tenggang rasa dan saling menghormati antara agama satu dengan yang lainnya.

d) Fungsional, memfungsikan ajaran masing-masing agama (termasuk agama Islam) terutama tentang pentingnya menghargai perbedaan dengan menekankan segi manfaat dan hikmahnya bagi peserta didik dalam kehidupan sehari-hari dengan tingkat perkembangannya. ${ }^{27}$

Dalam pendidikan, semua aspek kelembagaan dan proses belajar mengajarnya harus menerapkan sistem, metode, strategi dan kurikulum yang dapat menyembuhkan pluralisme serta mampu menggali sisi perdamaian dan toleransi. Oleh karenanya, di antara langkah yang ditempuh guru atau dosen, khususnya yang terkait dengan organisasi atau kegiatan pembelajaran di kelas adalah penentuan pendekatan dan metode. Hal tersebut merupakan elemen penting dalam proses belajar mengajar.

\section{Penutup}

Dunia pendidikan dituntut untuk lebih pro aktif untuk mengkampanyekan akan pentingnya penanaman nilai-nilai pluralisme, sehingga tindak kekerasan atau konflik atas nama agama dapat dihilangkan.

Kurikulum Pendidikan Islam hendaknya lebih menekankan akan pentingnya penanaman nilai-nilai pluralisme tersebut dalam kehidupan sehari-hari. Antara lain;

\footnotetext{
${ }^{27}$ Syamsul Ma'arif, The Baeuty of Islam “Dalam Cinta dan Pendidikan Pluralisme, h. 104-106.
} 
JURNAL PENDIDIKAN ISLAM IQRA'

Vol. 9. Nomor 1, Tahun 2015

Fakultas Tarbiyah dan Ilmu Keguruan [FTIK]

IAIN Manado

melaksanakan perbuatan yang baik, seperti tasamuh, toleransi, ta'awun dan akhlak lainnya.

Pluralisme sebenarnya adalah paham yang sangat diperlukan agar keanekaragaman dan kemajemukan tidak menjadi bagian konflik. Nilai-nilai dasar dari pluralisme itu adalah kesamaan dan kebersamaan, sikap terbuka dalam menerima perbedaan yang ada (saling memahami), saling menghormati, saling menolong, prinsip kebebasan, keadilan, persamaan hak dan kewajiban, kasih sayang, kebajikan, kedamaian, terbuka untuk melakukan kerja sama. 
JURNAL PENDIDIKAN ISLAM IQRA'

Vol. 9. Nomor 1, Tahun 2015

Fakultas Tarbiyah dan Ilmu Keguruan [FTIK]

IAIN Manado

\section{DAFTAR PUSTAKA}

Alex R. Rodger, Educational and Faith in Open Society, Britain: The Handel Press, 1982.

Amin Abdullah, Studi Agama: Normativitas atau Historisitas, Yogyakarta: Pustaka Pelajar, 1991.

Departemen Agama RI, Al-Qur'an dan Terjemahya Jakarta: Yayasan Penyelenggara Penterjemah al-Qur'an, 1971.

Dewan Redaksi Ensiklopedi Islam, Ensiklopedi Islam, Jilid IV, Jakarta: Ichtiar BaruVan Hoeve, 1994.

Departemen Pendidikan dan Kebudayaan, Kamus Besar Bahasa Indonesia, Jakarta: Balai Pustaka, 1990.

Gamal al-Banna, Doktrin Pluralisme dalam al-Qur'an, Jakarta: Menara, 2006.

Grolier, Encyclopedia of Knowledge, Jilid XV Danbury: Grolier Incorporated, 1993.

John Sealy, Religious Education Philosophical Perspective, London: George Allen \& Unwin, 1985.

M. Ainun Najib mengutip dari dari Syeikh Abdul Mahbub, "An Integrated Education System in A Multi-Faith and Multi-Cultural Country”,1991.

Moh. Natsir Mahmud, Bunga Rampi Epistemologi dan Metode Studi Islam, Ujung Pandang: IAIN Alauddin Ujung Pandang, 1998.

Nurcholis Madjid, Mencari Akar-Akar Islam bagi Pluralisme Modern, Bandung: Mizan, 1993).

Syamsul Ma'arif, Pendidikan Pluralisme di Indonesia Cet. I; Jogjakarta: Logung Pustaka, 2005.

Syafiq Hasyim, "Multikulturalisme Baru Barat-Islam”, Kompas, Sabtu, 3 Februari 2006.

Sayyed Husein Nasr, Filsafat Perenialisme Perspektif Alternatif untuk Studi Agama, diterjemahkan oleh Saeful Mazani dalam Jurnal Ulumul Qur'an, Vol. III, No. 3, Tahun 1992. 


\section{JURNAL PENDIDIKAN ISLAM IQRA'}

Vol. 9. Nomor 1, Tahun 2015

Fakultas Tarbiyah dan Ilmu Keguruan [FTIK]

IAIN Manado

Sayyed Husein Nasr, Knowlegde and The Sacred, diterjemahkan oleh Suharsono, dkk. Dengan judul Inteligensi dan Spiritualitas Agama-Agama Cet. I; Jakarta: Inisari Press, 2004. 